\title{
A Mathematical Model for Forecasting the Dam-Break Flood Routing Process of a Landslide Dam
}

\author{
Fugang Xu, ${ }^{1}$ Hongwei Zhou, ${ }^{1}$ Jiawen Zhou, ${ }^{1,2}$ and Xingguo Yang ${ }^{1}$ \\ ${ }^{1}$ State Key Laboratory of Hydraulics and Mountain River Engineering, Sichuan University, \\ Chengdu 610065, China \\ ${ }^{2}$ Key Laboratory of Mountain Hazards and Earth Surface Process, CAS, Chengdu 610044, China
}

Correspondence should be addressed to Jiawen Zhou, jwzhou@scu.edu.cn

Received 10 December 2011; Accepted 6 February 2012

Academic Editor: Paulo Batista Gonçalves

Copyright (C) 2012 Fugang Xu et al. This is an open access article distributed under the Creative Commons Attribution License, which permits unrestricted use, distribution, and reproduction in any medium, provided the original work is properly cited.

Once a landslide dam bursts, its reservoir discharges quickly in a flood which will cause catastrophic damage to life and property downstream. For a specific landslide dam, the peak flow rate and the evolution of downstream flood are influenced by the shape and size of the dike breach when dam-break occurs. According to the general nature of landslide dams and field observations of dike-breach development patterns, a dike-breach propagation mode has been determined. By combining an improved empirical equation with knowledge of the dike-breach propagation mode, a mathematical model for forecasting dam-break flood routing has been developed and is presented here. Sensitivity analysis was then carried out based on the computed results for peak flow rate and the flood evolution curve under different parameters. The computed results showed that the width coefficient and the depth coefficient had similar effects on the dam-break flood but that the impact of the depth coefficient was more significant than that of the width coefficient. Finally, the proposed model was used to calculate the flood evolution for the Tangjiashan landslide dam. The computed results showed that the error between the simulated result and the measured data was less than $5 \%$.

\section{Introduction}

When a dam is breached or destroyed, a large amount of water is released suddenly in a flood wave which is likely to cause catastrophic damage to life and property downstream and to exert a detrimental influence on the downstream ecology and environment [1]. Since 1954, approximately 2900 dam-break events have occurred in China (meaning that the proportion of dams breaking during this period was approximately 3.4\%), with more than 710 events in the 1960s and more than 1900 events after 1970. With the increasing number of natural 
landslide dams and manmade dams, preventing dam-break events has become a substantial challenge for engineers and governments [2]. In August 1975, two large dam-break events (at Banqiao and at Shimantan) took place in Henan province. These were typical dam-break events and caused huge losses of life and property. Over the same period, the major typical dam-break accidents outside China were the Teton dam-break (an earth dam) in the United States and the failure of the Malpasset arch dam in France, which also caused many casualties and large property losses.

A landslide dam is a special kind of natural dam generated by geological hazards such as rock falls, debris flows, debris avalanches, or other landslide events $[3,4]$. The dam-break process for a landslide dam is more complicated than for artificial earth-rock dams, and there exists now no reasonable explanation for its dam-break mechanism [5]. The failure processes of a landslide dam are gradual, may destroy the dam over a short time, and sometimes are manifested as an instant break [6]. Computing dam-break floods is a key issue for understanding and preventing breaks of landslide dams. Empirical models usually consider a series of parameters (such as the particle size of the dam material, the internal friction angle, the porosity, and the depth-to-width ratio of the dike breach), which are used to simulate the dam-break flood routing process. Dam-break flood evolution involves various direct factors which determine the severity of a disaster. Computational methods for downstream flood evolution include one-dimensional models, two-dimensional models, and generalized empirical equation methods [7]. The dam-break flood routing process is related to the form of the dam-break, the maximum flow rate, the inflow, and the downstream water level, but the computation of the dam-break flood routing process is a difficult problem. Many researchers have studied this problem extensively and have achieved a number of advances. Many physical and mathematical models have been presented to compute dambreak floods; the most representative are the BEED model [8], the BREECH model [8], and the DAMBRK model [9]. In addition, many empirical equations have been proposed for forecasting peak flow at a dam site, such as the Saint-Venant equation, the Ritter equation, the Stocker equation, the Thakar equation, and the Shockley equation [10]. The accuracy of the simulated results for dam-break flooding is influenced by the shape of the dike breach and the upstream water flow.

A trapezoidal dike breach is assumed here to compute the dam-break flood for a landslide dam; three important parameters are defined, the width coefficient $k_{1}$, the depth coefficient $k_{2}$, and the inclination of the dike breach $z$. By combining these with an empirical equation, a mathematical model for forecasting dam-break flood has been developed and is presented here. A sensitivity analysis was carried out involving the peak flow rate, the downstream flood evolution, the width coefficient $k_{1}$, the depth coefficient $k_{2}$, and the dike breach inclination $z$. Finally, this model has been used to simulate the dam-break flood of the Tangjiashan landslide dam, which released the largest landslide-dam lake in China, which had been created by the May 12 Wenchuan earthquake.

\section{Forecasting Model for Dam-Break Floods}

When a dam is breached, the water behind it is released at high speed under gravity, and water flows continually through the dam body, which continually increases the dike breach until the water level has been substantially decreased or until the dam can resist further water erosion [11]. The reservoir water passing through the breach results in a large flow routing 


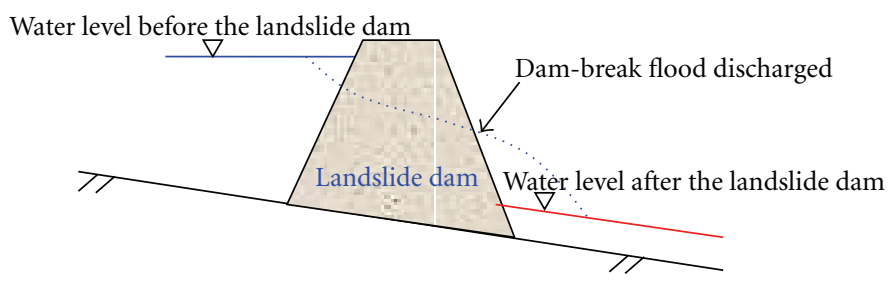

Figure 1: Schematic diagram of the dam-break flood problem.

towards downstream areas. If the maximum flow rate is more than a certain value, the dambreak flood will cause a large disaster for life and property downstream. Figure 1 shows a schematic diagram of the dam-break flood problem.

As shown in Figure 1, after the dam has breached, the reservoir water will rush downstream. The key issues are the peak flow rate downstream, the water flow process at the dam site, and the flood routing process downstream.

\subsection{Assumptions Regarding Dike Breach}

In the simulation of the dam-break flood process, the simulated results are influenced by the shape and the progressive expansion process of the dike breach. The classic models for dikebreach simulation are the HW model [12], the Nogueira model [13], the BREACH model, and the BEED model. Each model is based on different assumptions for the dike-breach shape; for example, the HW model assumes that the dike breach is a trapezoid, while the BEED model assumes a rectangular dike breach. The shape of real dike breaches has been observed to be trapezoidal, which is in accordance with the characteristics of flow erosion. This research assumes a trapezoidal dam breach. Figure 2 shows the assumed shape of the dike breach.

As shown in Figure 2, the dike-breach shape depends mainly on three parameters: the breach depth $h$, the breach bottom width $b$, and the breach inclination $z$. The relation of the breach bottom width $b$ and the top width $B_{0}$ is as follows: $b=B_{0}-2 h z$. The relationships of dike-breach width and depth and landslide-dam width and height can be expressed as

$$
B_{0}=k_{1} B, \quad h=k_{2} H,
$$

where $B$ is the width of the landslide dam, $B_{0}$ is the top width of the dike breach, $k_{1}$ is the width coefficient, $H$ is the height of the landslide dam, $h$ is the depth of the dike breach, and $k_{2}$ is the depth coefficient. Parameters $k_{1}$ and $k_{2}$ are less than 1.0; when $k_{1}=1.0, k_{2}=1.0$, the dike breach is the same size as the landslide dam. Then, the bottom width of the dike breach can be expressed as

$$
b=k_{1} B-2 k_{2} H z .
$$

The shape of the dike breach depends on the geometric parameters described above; rectangular and triangular shapes can be regarded as special cases of a trapezoid. For a rectangular dike breach, $b>0$ and $z=0$; for a triangular dike breach, $b=0$ and $z>0$; for a trapezoidal dike breach, $b>0$ and $z>0$. Here, it is assumed that the breach inclination 


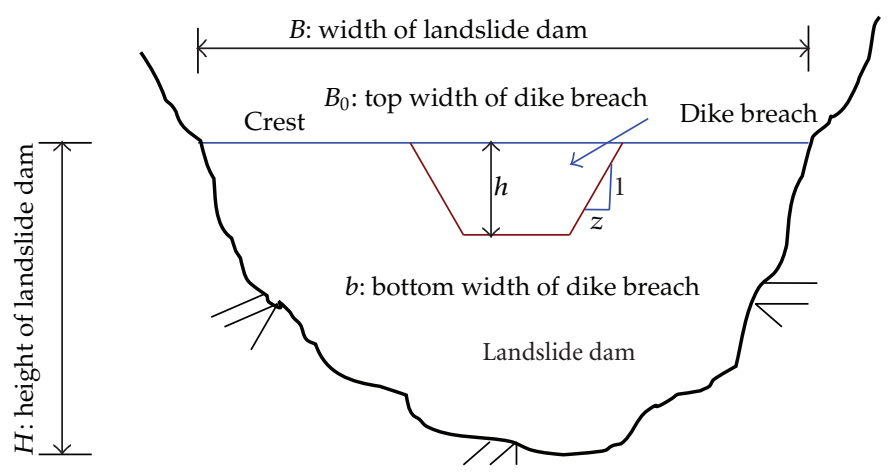

Figure 2: Assumed shape of dike breach.

parameter $z$ has a fixed value and that the bottom width and depth vary according to a linear relationship.

\subsection{Peak Flow}

Based on different assumptions, existing forecasting models (such as the Saint-Venant equation or the Ritter equation) for peak flow mostly consider breaches involving one-half or one-third of the dam or else the entire dam. However, if the dam-break occurs in one part of the landslide dam, and, if the shape of the dike breach is a trapezoid, then the size of the dike breach will vary according to the mechanical characteristics of the landslide dam and the water flow properties upstream. Here, an empirical equation used by American waterways experimental stations was used to compute the peak flow rate of dam-break floods and to make some modifications to this equation. The coefficient $\lambda$ refers to the Xierenzhi unified equation [14] and accounts for the impact of the width, depth, and inclination of the dike breach:

$$
Q_{\max }=\lambda k_{1}^{0.72} k_{2}^{1.22} B \sqrt{g} H^{3 / 2}
$$

where $Q_{\max }$ is the maximum flow rate at the dam site, $\mathrm{m}^{3} / \mathrm{s} ; B$ is the length of the dam, $m ; H$ is the water depth upstream before the dam-break, $m ; k_{1}$ is a width coefficient; $k_{2}$ is a depth coefficient; $g$ is the acceleration of gravity, $9.8 \mathrm{~m} / \mathrm{s}^{2} ; m$ is a cross-sectional shape index which can be computed as follows:

$$
m=\frac{\log \left(\left(b h+h^{2} z\right) /(b+z)\right)}{\log h}=\frac{\log \left(\left(k_{1} k_{2} B H\right) /\left(k_{1} B-\left(k_{2} H-1\right) z\right)\right)}{\log k_{2} H} .
$$

The parameter $\lambda$ can then be calculated as [14]:

$$
\lambda=m^{m-1}\left[\frac{2 \sqrt{m}}{1+2 m}\right]^{2 m+1} .
$$


Here, the dike flow is assumed as a continuous wave flow. Assuming a fixed reservoir, if the water depth upstream of the landslide dam before the dam-break is $H$ and the total width is $B$ (these two parameters can be obtained by field observation; here assumed values are used), then

$$
a=B \sqrt{g} H^{1.5}
$$

Then, (2.3) can be rewritten as follows:

$$
Q_{\max }=\lambda k_{1}^{0.72} k_{2}^{1.22} a
$$

The value of $Q_{\max }$ is related to the width coefficient $k_{1}$, depth coefficient $k_{2}$, and inclination $z$.

\subsection{Flow Process at the Dam Site}

For calculating the flow process at the dam site, there are two kinds of methods in general. One type begins with a complete equation combined with flow conditions at the dam site. A theoretical solution or a partial theoretical solution for the flow process at the dam site is obtained based on the mathematical theory of partial differential equations and ordinary differential equations, which is then used to compute the water flow curve at the dam site. This method considers the various factors in a comprehensive manner, but the calculations are very complex, which makes this method hard to use in practice. A second type of method performs the computations based on a generalized typical flow process curve. In practice, a fourth-order parabolic equation is often used to compute the flow process at the dam site. Figure 3 shows the flow process curve at the dam site based on a fourth-order parabolic equation.

In Figure 3, $Q$ is the initial water flow at the dam site, $t$ is the flow time, $Q_{0}$ is the steady-state water flow after a long time, and the water flow at the dam site decreases over time. By examination of field measurements and existing research, it was determined that a fourth-order parabolic equation is well suited to simulate the flow process curve at the dam site and that an approximate expression for the flow curve is the following:

$$
Q-Q_{0}=k(t-T)^{4}+c
$$

where $T$ is an uncertain time parameter, $c$ is a constant of water flow, and $k$ is an unknown parameter to be determined.

The water flow process at the dam must satisfy the following assumptions:

$$
\begin{gathered}
Q=Q_{\max }, \quad t=0, \\
Q=Q_{0}, \quad t=T, \\
\int_{0}^{T} Q d t=W,
\end{gathered}
$$

where $W$ is the reservoir capacity of the landslide-dammed lake. 


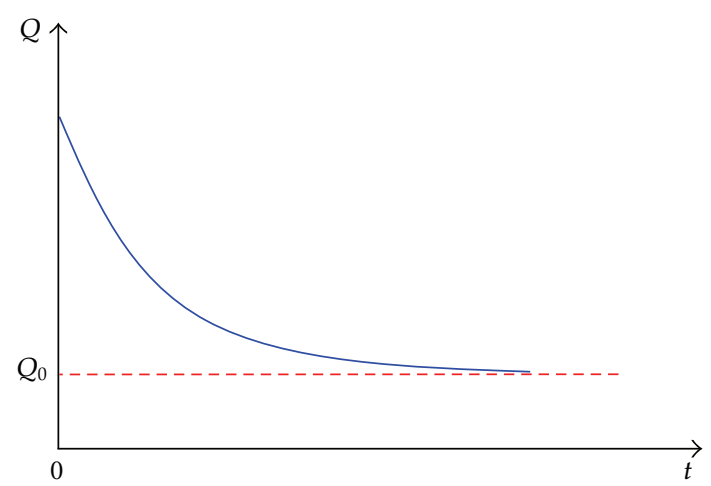

Figure 3: Flow process curve at the dam site based on a fourth-order parabolic equation.

According to (2.8), combined with the boundary condition in (2.9), the unknown parameters $T$ and $k$ can be obtained as follows:

$$
\begin{aligned}
T & =\frac{5 W}{Q_{\max }+4 Q_{0}}, \\
k & =\frac{Q_{\max }-Q_{0}}{T^{4}} .
\end{aligned}
$$

Equation (2.8) can then be rewritten as follows:

$$
Q=\left(Q_{\max }-Q_{0}\right)\left(\frac{t}{T}-1\right)^{4}+Q_{0}
$$

If the maximum flow rate is known to be $Q_{\max }$, the discharge flow before the dambreak is $Q_{0}$, and the reservoir capacity of the dammed lake is $W$, then the flow process at the dam site can be determined. In practice, $Q_{0}$ is much smaller than $Q_{\max }$. Here, $Q_{0}$ was assumed to be zero to simplify the computations, yielding

$$
Q=Q_{\max }\left(\frac{Q_{\max }}{5 W} t-1\right)^{4}
$$

As shown in (2.12), the water flow $Q$ decreases over time when $Q_{\max }$ is a fixed value. Combining (2.12) with (2.7),

$$
Q=\lambda k_{1}^{0.72} k_{2}^{1.22} a\left(\frac{\lambda k_{1}^{0.72} k_{2}^{1.22} a}{5 W} t-1\right)^{4}
$$

As shown in (2.13), the water flow $Q$ at the dam site is indirectly influenced by the width coefficient $k_{1}$, the depth coefficient $k_{2}$, and the inclination $z$. 


\subsection{Flood Routing Process at the Downstream}

The flood routing process downstream can be computed by a one-dimensional model or a two-dimensional model [7], but the calculations are very complex; if a typical generalized empirical equation is used, the calculations are simplified, and computation speed is increased. Among several empirical equations for the flood routing process, the Xierenzhi equation was used in this research to compute the downstream flood routing process because it is well suited for the landslide dam at mountain river and also considers channel characteristics [14]:

$$
Q_{\mathrm{mx}}=Q_{\max }\left(\frac{1}{1+\left((2-\gamma) \lambda^{\prime} n^{2-\gamma} Q_{m 0}^{2-\gamma} / i_{0}^{(2-0.5 \gamma)} W^{2}\right) x}\right)^{1 /(2-\gamma)} .
$$

By combining this equation with the flow process at the dam site, the parameters of (2.14) can be obtained:

$$
\gamma=\frac{0.33}{m+0.67}, \quad \lambda^{\prime}=\frac{1.32 A^{r} m^{(0.33-0.67 \gamma)}}{\gamma(m+1)^{2}}, \quad A=\left(k_{1} B-z\right) H^{m},
$$

where $A$ and $m$ are, respectively, the coefficient and the index of the river section; $Q_{\max }$ is the maximum flow at the dam site; $Q_{\mathrm{mx}}$ is the maximum flow at a point at a distance $x$ downstream of the dam site; $W$ is the reservoir storage capacity; $i_{0}$ is the slope of the river channel; $n$ is the Manning roughness coefficient.

\section{Sensitivity Analyses of the Model Parameters}

In the simulation of the dam-break flood process, the flow discharge through the dike breach and the flood evolution downstream are influenced by the parameters of the mathematical model. This paper considers mainly the influence of breach shape, which includes the width coefficient $k_{1}$, the depth coefficient $k_{2}$, and the breach inclination $z$. With different values of the width coefficient $k_{1}$, depth coefficient $k_{2}$, and breach inclination $z$, the shape and size of the dike breach vary, taking on forms such as a triangle, a rectangle, or a trapezoid. Through sensitivity analysis of the mathematical model parameters, the influence of each parameter on the maximum flow downstream and the maximum flow at the dam site can be determined. With this information, the risk and impact of a dam-break flood disaster can be evaluated.

\subsection{Model Parameters}

The selection of model parameters is based on the actual situation of the Tangjiashan landslide-dammed lake. The size and shape of the dike breach, the water level behind the landslide dam, and the slope and roughness of the river channel are considered for the sensitivity analysis. Certain basic parameters were set based on field investigation and hydrogeological data. For the breach inclination $z$, in reference to the actual situation of the dike breach at the Tangiiashan landslide dam, the value $z=\tan \left(45^{\circ}+\psi / 2\right)$ was chosen, where $\psi$ is the internal friction angle of the dam materials. 
For a typical landslide dam, the water reservoir capacity of the landslide-dammed lake is $W$, the water depth behind the dam is $H_{0}$, and the distance of one point far away from the dam site is $L$. These are fixed values which can be obtained from hydrogeological data. However, the width coefficient $k_{1}$, the depth coefficient $k_{2}$, and the breach inclination $z$ are not known. Take the Tangjiashan dammed lake as an example to select the model parameters. Given the materials composition and the form factor of the landslide dam, and in particular its current stability status, the internal friction angle $\psi$ of the dam material is $26^{\circ}$, so that the breach inclination $z$ is equal to 1.60. Given that the water depth behind the Tangjiashan landslide dam is $82.65 \mathrm{~m}$, the slope of the downstream channel is $i_{0}=2.5 \%$, and the river roughness $n$ is between 0.035 and 0.050 and taking into account the actual condition of the soil at the Tangjiashan landslide dam, a value of $n=0.050$, the maximum value of river roughness, was chosen for this analysis.

\subsection{Sensitivity Analysis Results}

The proposed mathematical model for forecasting the dam-break flood routing process of a landslide dam was implemented using the FORTRAN programming language. The discharge flow at the dam site and the flow evolution process downstream were computed under different values of the width coefficient $k_{1}$ and depth coefficient $k_{2}$. Figure 4 shows the simulated results of peak flow downstream under different values of width coefficient $k_{1}$ and depth coefficient $k_{2}$.

As shown in Figure 4, when the width coefficient $k_{1}$ is fixed, the maximum flow $Q_{\max }$ increases with increasing values of the depth coefficient $k_{2}$. When the depth coefficient $k_{2}$ is fixed, the maximum flow $Q_{\max }$ increases with increasing values of the width coefficient $k_{1}$. Comparing the maximum flow increase with the width coefficient $k_{1}$ and that with the depth coefficient $k_{2}$, the maximum flow through the dam-break was found to be influenced more significantly by the depth coefficient $k_{2}$ than by the width coefficient $k_{1}$. The discharge water flow depends on the area of the dike breach, according to practical experience with landslide dams; the area of the dike breach is usually very small, and therefore the discharge water flow is less than the water flow upstream. However, the size of the dike breach increases because the rock and soil particles are eroded by the high-speed water flow.

Figure 5 shows the simulated results of water flow at the dam site over time under different values of the width coefficient $k_{1}$, with the depth coefficient $k_{2}$ held constant at 0.5. Figure 6 shows the simulated results of water flow at the dam site over time under different values of the depth coefficient $k_{2}$, with the width coefficient $k_{1}$ held constant at 0.5 .

As shown in Figures 5 and 6, at the dam site, the water flow increases with the width coefficient $k_{1}$ when the depth coefficient $k_{2}$ is held constant; when the width coefficient $k_{1}$ is held constant, larger values of the depth coefficient $k_{2}$ are associated with larger flows. The influence of the depth coefficient $k_{2}$ on the water flow at the dam site is more significant than that of the width coefficient $k_{1}$. The water flow at the dam site decreases over time and then maintains a constant flow with a certain width coefficient and depth coefficient. The total time to discharge the reservoir water capacity depends on the area of the dike breach. Therefore, a large-area dike breach can be used to discharge the reservoir water capacity as an emergency measure for a landslide-dammed lake.

Figure 7 shows, for depth coefficient $k_{2}=0.5$, the corresponding flood routing curves for different width coefficients $k_{1}$; Figure 8 shows, for width coefficient $k_{1}=0.5$, the corresponding flood routing curves for different depth coefficient $k_{2}$. 


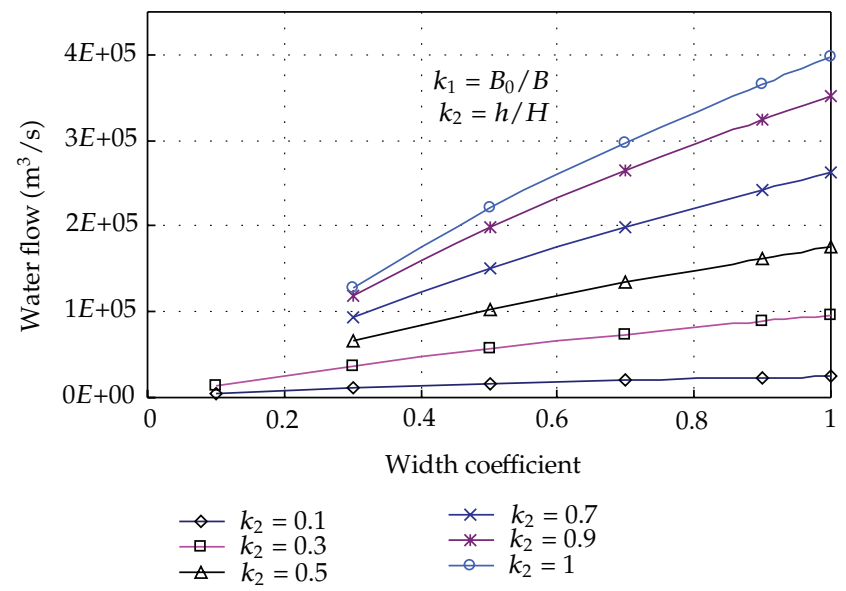

Figure 4: Simulated results of peak flow downstream under different values of width coefficient $k_{1}$ and depth coefficient $k_{2}$.

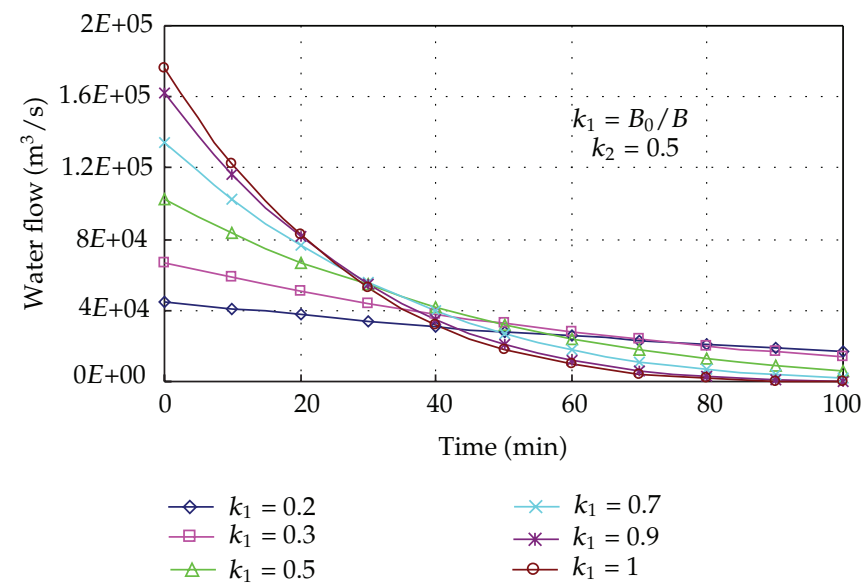

Figure 5: Simulated results of water flow at the dam site over time under different values of the width coefficient $k_{1}$ (with the depth coefficient $k_{2}$ held constant at 0.5 ).

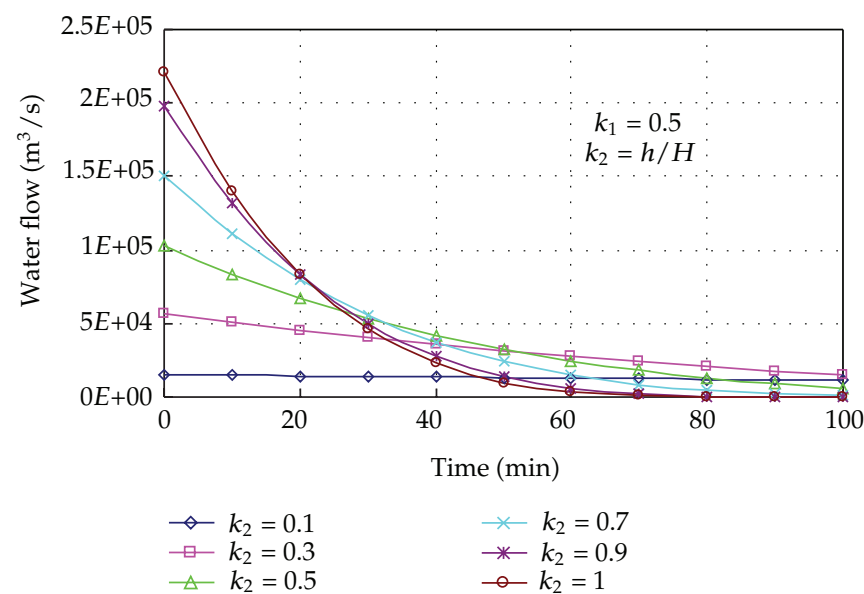

Figure 6: Simulated results of water flow at the dam site over time under different values of the depth coefficient $k_{2}$ (with the width coefficient $k_{1}$ held constant at 0.5 ). 


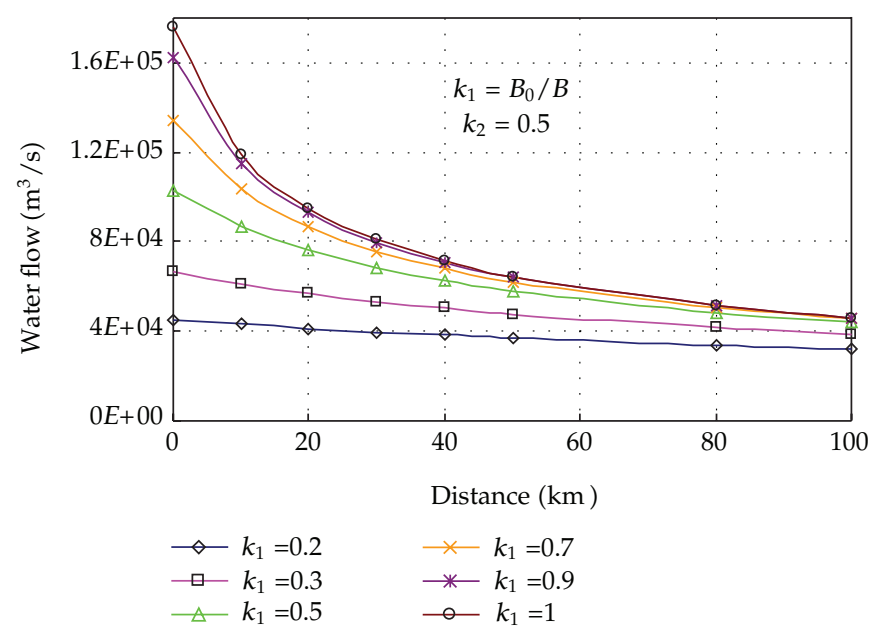

Figure 7: Simulated results of the flow routing process along the downstream river channel under different values of the width coefficient $k_{1}$ (with the depth coefficient $k_{2}$ held constant at 0.5 ).

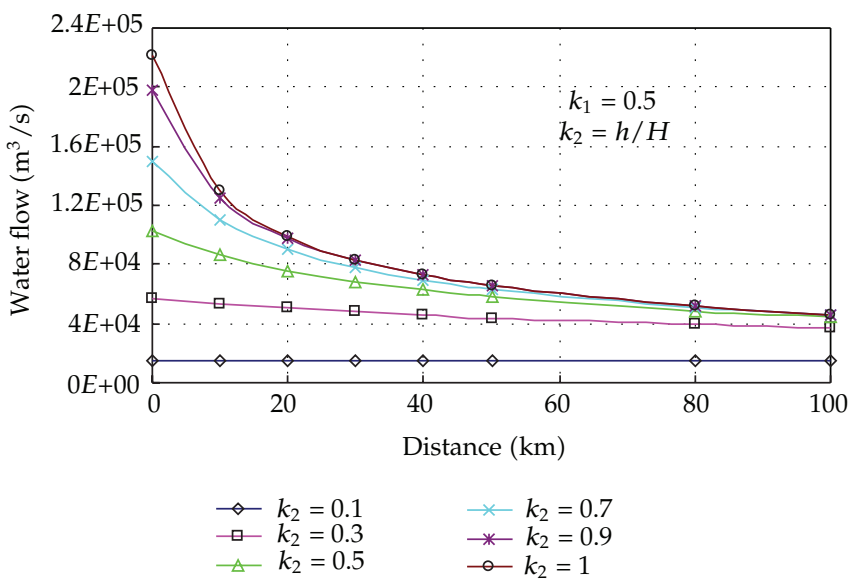

Figure 8: Simulated results of the flow routing process along the downstream river channel under different values of the depth coefficient $k_{2}$ (with the width coefficient $k_{1}$ held constant at 0.5 ).

As shown in Figures 7 and 8, for a given section of downstream river channel, the water flow increases as the width coefficient $k_{1}$ increases, with the depth coefficient $k_{2}$ held constant. When the width coefficient $k_{1}$ is held constant, the larger the depth coefficient $k_{2}$, the larger is the water flow. The water flow in a given section of downstream river channel is influenced more by the depth coefficient $k_{2}$ than by the width coefficient $k_{1}$. The water flow decreases with increasing distance between a particular flow section downstream and the dam site. The dam-break flow routing process is influenced by the shape of the dike breach, especially for flow sections close to the dam site, where the influence is significant, but if the given flow section is far away from the dam site, the influence on water flow value of the dike-breach shape is not significant.

This sensitivity analysis of the parameters of the presented model for the dam-break flood routing process of a landslide dam has shown that the flood discharge at the dam site 
and the flood evolution downstream are significantly influenced by the shape of the dike breach and especially by the depth coefficient $k_{2}$.

\section{Simulation of the Dam-Break Flood of the Tangjiashan Landslide Dam}

\subsection{Engineering Background}

The Tangjiashan dammed lake is the biggest of the landslide-dammed lakes triggered by the May 12 Wenchuan earthquake, Sichuan Province, Southwest China [15]. The dam is located in Beichuan County and is mainly composed of soil, with some rock blocks. The water reservoir capacity of the Tangjiashan dammed lake was approximately $315 \times 10^{8} \mathrm{~m}^{3}$, the length was approximately $803.4 \mathrm{~m}$, the width was approximately $611.8 \mathrm{~m}$, and the depth was approximately $100 \mathrm{~m}$ [16]. Figure 9 shows an onsite photo of the Tangjiashan dammed lake. The largest water depth behind the dam was approximately $82.65 \mathrm{~m}$. Soon after the landslidedammed lake formed, the rainy season arrived, and therefore the water level and the reservoir capacity increased over a short time. On June 10, 2008, the highest water level was approximately $743.10 \mathrm{~m}$, the corresponding water reservoir capacity was approximately $244.62 \times 10^{8} \mathrm{~m}^{3}$, and the landslide dam was in a dangerous state. If the Tangjiashan landslide dam were to burst, the dam-break flood would cause a huge disaster for people and property downstream.

Figure 10 shows the relationship between the water level and the reservoir capacity of the Tangjiashan landslide-dammed lake.

As shown in Figure 10, when the water level in front of the landslide dam increased over a short time and then maintained the higher water level, the water pressure created a risk to the stability of the landslide dam. If the water flow in the rainy season were large, the water would overtop the dam and the landslide dam would be destroyed, causing huge floods downstream. Figure 11 shows the results of monitoring the water inflow to the Tangjiashan landslide-dammed lake upstream.

As shown in Figure 11, the water inflow to the Tangjiashan landslide-dammed lake was very large between May 12, 2008 and June 10, 2008. The average water inflow was approximately $100 \mathrm{~m}^{3} / \mathrm{s}$, and the maximum water inflow, approximately $175 \mathrm{~m}^{3} / \mathrm{s}$, occurred on May 20, 2008.

\subsection{Water Flow Process after the Excavation of a Diversion Channel}

The water level behind the Tangjiashan landslide dam increased over a short time; to reduce the risk to the Tangjiashan dammed lake, an emergency man-made excavated dike breach was used to discharge the water flow. The length of the diversion channel was $670 \mathrm{~m}$, the height was $12 \mathrm{~m}$, the bottom elevation was $740 \mathrm{~m}$, the section was an opposite trapezoid, and the bottom width was approximately $10 \mathrm{~m}$. Figure 12(a) shows the excavated diversion channel used to discharge the water flow.

At 9:35 AM on June 10, the water level behind the dam began to change and the diversion channel width rapidly increased. About six hours later, the area of the diversion channel showed no evidence of further change, and erosion of the landslide dam was maintained in a stable state over the following time period. The discharge of water flow through an excavated diversion channel can be divided into three stages: (1) initial water flow through 


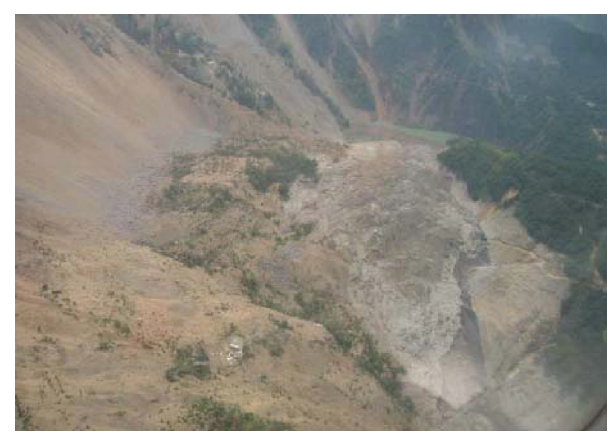

Figure 9: Onsite photo of the Tangjiashan landslide-dammed lake.

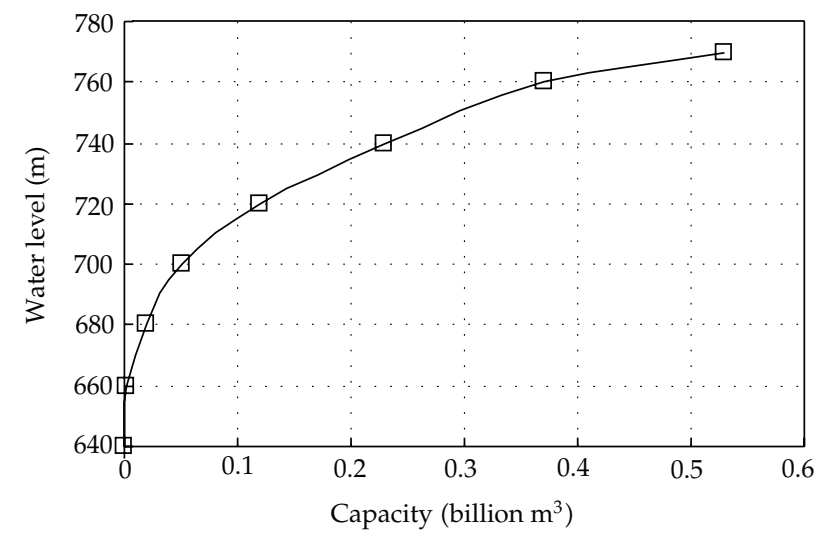

Figure 10: Relationship between water level and reservoir capacity of the Tangjiashan landslide-dammed lake.

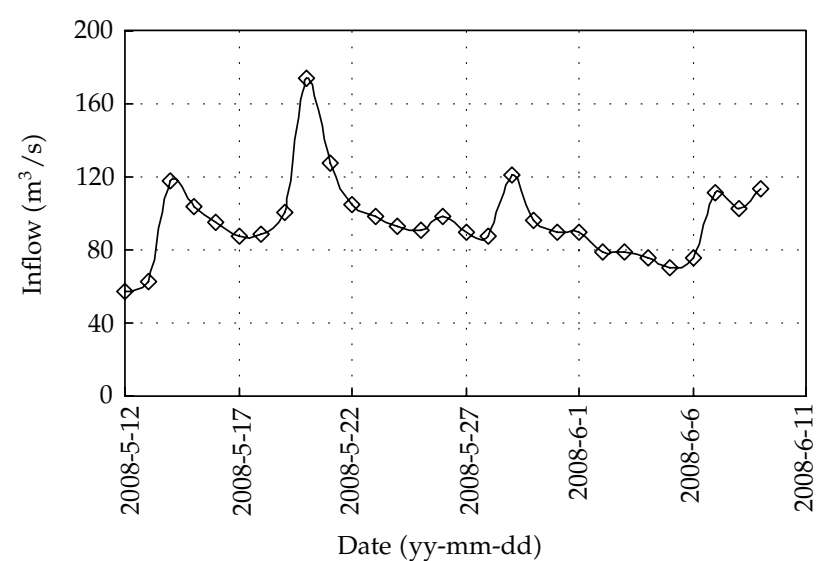

Figure 11: Results of monitoring the water inflow to the Tangjiashan landslide-dammed lake upstream.

the diversion channel, with slight erosion of the landslide dam; (2) gradually increasing velocity of the water flow, with substantial erosion of the landslide dam. The area of the diversion channel will increase until the water flow reaches its maximum value; (3) decrease in the rate and velocity of the water flow, at which point the erosion of the landslide dam stops and the dam remains in a stable state. 


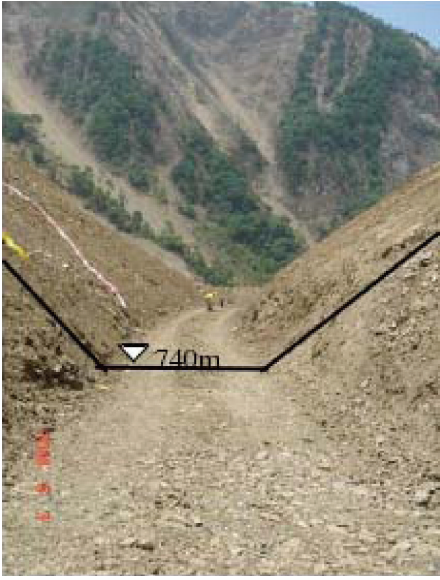

(a)

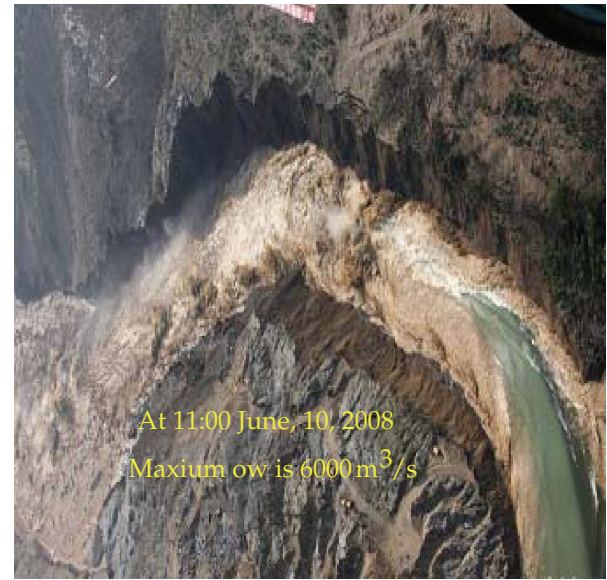

(b)

Figure 12: (a) Excavation diversion channel used to discharge the water flow; (b) discharge state of water flow from the Tangjiashan landslide-dammed lake.

Figure 12(b) shows the state of the discharge water flow at the Tangjiashan landslidedammed lake at 11:00 AM, June, 10, 2008.

As shown in Figure 12(b), the velocity of the water flow is high, and therefore erosion of the excavated channel is serious. Field measurements on June 23 of the diversion channel after the erosion caused by the high-speed water flow revealed that the depth of diversion channel was approximately $47 \mathrm{~m}$, the bottom elevation was approximately $705 \mathrm{~m}$, and the bottom width was approximately $140 \mathrm{~m}$. Figure 13 shows the size of the excavated diversion channel before and after water-flow erosion.

As shown in Figure 13, the initial bottom width of the excavated diversion channel was $7 \mathrm{~m}$ and the height was $12 \mathrm{~m}$. After erosion by high-speed water flow, the width of the diversion channel was increased to $140 \mathrm{~m}$ and the height was increased to $47 \mathrm{~m}$.

Figure 14 shows the flood discharge curves of the initial excavated dike breach and of the stable dike breach after erosion by water flow.

\subsection{Comparison with Measured Data}

After the diversion channel was excavated, the water level behind the landslide dam did not change significantly, but, because the velocity of the water flow was high, erosion of the diversion channel was very obvious. Then, the area of diversion channel increased over a short time, the flow discharge increased gradually, the velocity of the water flow decreased, and the water level decreased to reach stable value. Figure 15 shows a comparison of calculated and measured water flows downstream of the Tangjiashan landslide dam.

As shown in Figure 15, the calculated water flows downstream was close to the measured data, with the water flow decreasing with increasing distance between the monitored section and the dam site. Table 1 shows the simulated and measured maximum discharge flows downstream of the Tangjiashan landslide-dammed lake.

As shown in Table 1, the error in the simulated maximum water flow at the Tangjiashan dam was $-4.246 \%$, the error at the Beichuan station was $-4.908 \%$, the error at 


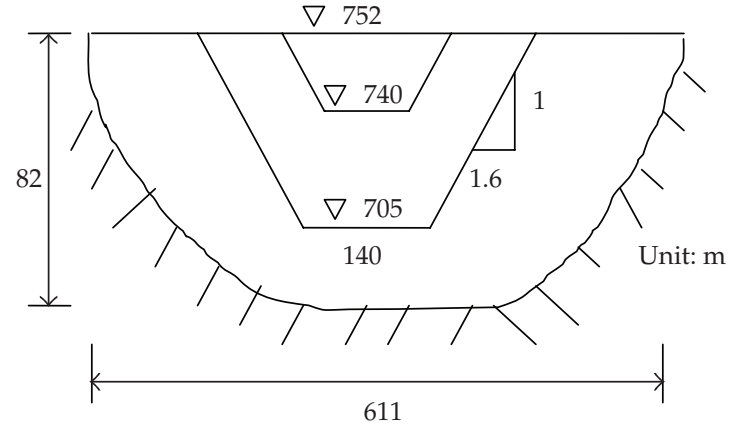

Figure 13: Size of the excavated diversion channel before and after erosion by water flow.

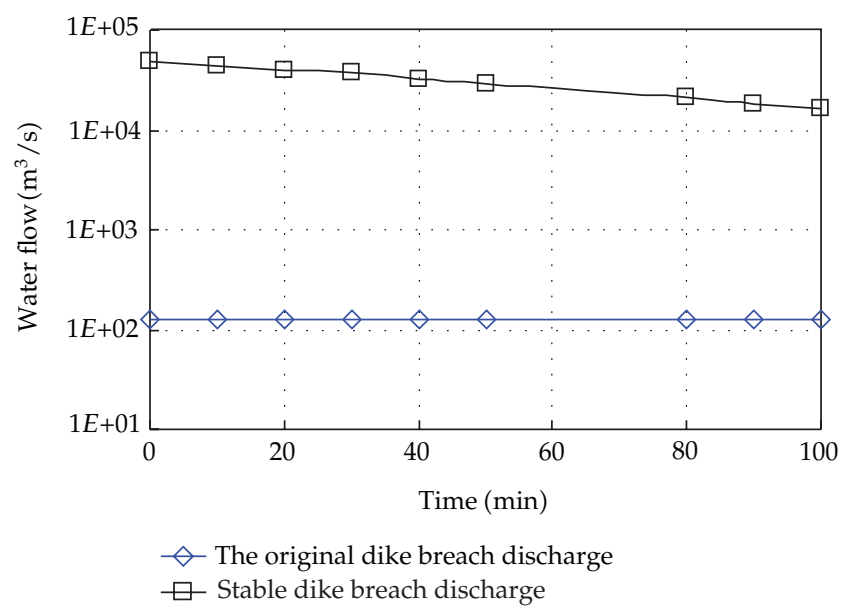

Figure 14: Flood discharge curve of the initial excavated dike breach and the stable dike breach after erosion by water flow.

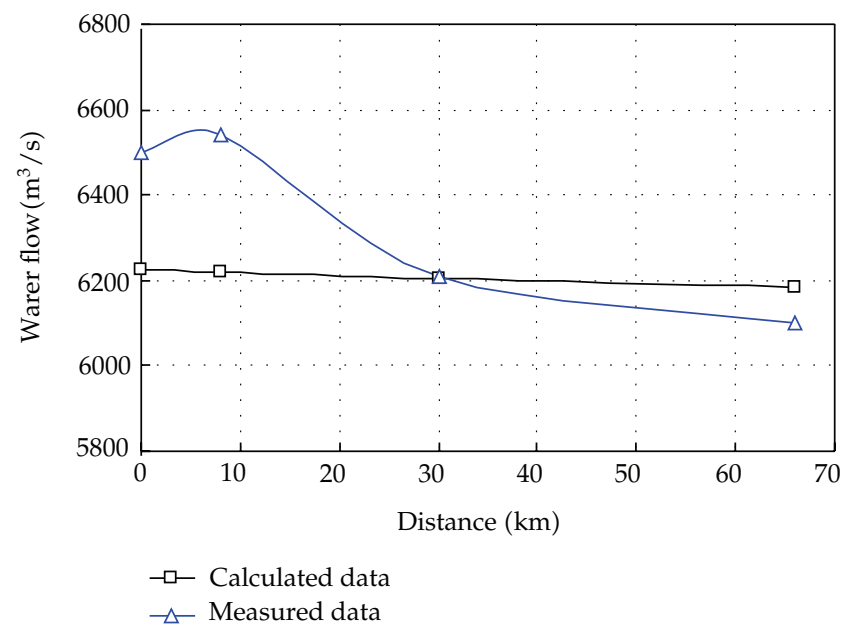

Figure 15: Comparison of calculated and measured water flows downstream of the Tangjiashan landslide dam. 
Table 1: Simulated and measured maximum discharge downstream of the Tangiiashan landslide-dammed lake.

\begin{tabular}{lccccc}
\hline $\begin{array}{l}\text { Downstream } \\
\text { monitoring station }\end{array}$ & $\begin{array}{c}\text { Distance } \\
(\mathrm{km})\end{array}$ & Peak time & $\begin{array}{c}\text { Measured } \\
\text { maximum flow } \\
\left(\mathrm{m}^{3} / \mathrm{s}\right)\end{array}$ & $\begin{array}{c}\text { Calculated } \\
\text { maximum flow } \\
\left(\mathrm{m}^{3} / \mathrm{s}\right)\end{array}$ & Error \% \\
\hline Tangjiashan dam & 0 & $2008-6-1012: 30$ & 6500 & 6224 & -4.246 \\
Beichuan station & 8 & $2008-6-1013: 30$ & 6540 & 6219 & -4.908 \\
Tongkou station & 30 & $2008-6-1014: 24$ & 6210 & 6205 & -0.081 \\
Fujiaqiao station & 66 & $2008-6-1017: 18$ & 6100 & 6183 & 1.361 \\
\hline
\end{tabular}

the Tongkou station was $-0.081 \%$, and the error at the Fujiaqiao station was $1.361 \%$. It can be concluded that the simulated results are reasonable and can be used for forecasting the dam-break flood routing process of landslide-dammed lakes.

\section{Conclusions}

Through analysis of existing models and practical examples, the shape of a dike breach in a landslide dam was here assumed to be a trapezoid. Based on existing empirical equations and with several improvements in the forecasting models for dam-break floods, a mathematical model is proposed in this paper for forecasting the dam-break flood routing process of landslide dams. The maximum flow rate, the flow process at the dam site, and the flow process downstream can be simulated using this model. A sensitivity analysis of the model parameters was also carried out. The results showed that the dam-break flood process is obviously influenced by the shape of the dike breach and especially significantly influenced by the depth coefficient $k_{2}$. Finally, the proposed model was used to simulate the flow process of the Tangiiashan landslide-dammed lake and to analyze the water flow and the diversionchannel erosion process. Results showed that initially the peak flow in the excavated dike breach was very small but that the peak flow of the stable dike breach after erosion by water flow became very large. The error in the maximum simulated flow rates downstream of the Tangjiashan landslide dam was less than $5 \%$, and therefore the results of simulation using the presented model can be considered to be reasonable.

The proposed model can simulate the dam-break evolution process of all dike breach sizes for the Tangjiashan dammed lake which could possibly occur, the maximum discharge flow and the maximum flow downstream. The model can provide support for decisionmaking by governments regarding landslide-dammed lakes. Although the proposed model of the dam-break flood problem considers the width coefficient and depth coefficient of a dike breach, it is a two-dimensional model and cannot accommodate the impact of certain important factors which impact dam-break flooding. In fact, dam-break flooding and flow evolution process are three-dimensional problems, but it is difficult to establish theoretical equations to simulate a dam-break flood in three dimensions. The numerical simulation approach is therefore a useful tool for computing a three-dimensional dam-break flood.

\section{Acknowledgment}

This work is granted by the National Natural Science Foundation of China (Grant no. 41102194). 


\section{References}

[1] S. Soares-Frazão and Y. Zech, "Dam-break flow through an idealised city," Journal of Hydraulic Research, vol. 46, no. 5, pp. 648-658, 2008.

[2] P. Cui, Y. S. Han, C. Dang, and X. Q. Chen, "Formation and Treatment of Landslide Dams Emplaced During the 2008 Wenchuan Earthquake, Sichuan, China," in Natural and Artificial Rockslide Dams, vol. 133 of Lecture Notes in Earth Sciences, pp. 295-321, Springer, Berlin, Germany, 2011.

[3] O. Korup, "Recent research on landslide dams-a literature review with special attention to New Zealand," Progress in Physical Geography, vol. 26, no. 2, pp. 206-235, 2002.

[4] J. Zhuang, P. Cui, K. Hu, X. Chen, and Y. Ge, "Characteristics of earthquake-triggered landslides and post-earthquake debris flows in Beichuan County," Journal of Mountain Science, vol. 7, no. 3, pp. 246254, 2010.

[5] J. W. Zhou, W. Y. Xu, X. G. Yang, C. Shi, and Z. H. Yang, “The 28 October 1996 landslide and analysis of the stability of the current Huashiban slope at the Liangjiaren Hydropower Station, Southwest China," Engineering Geology, vol. 114, no. 1-2, pp. 45-56, 2010.

[6] S. A. Dunning, N. J. Rosser, D. N. Petley, and C. R. Massey, "Formation and failure of the Tsatichhu landslide dam, Bhutan," Landslides, vol. 3, no. 2, pp. 107-113, 2006.

[7] S. W. Bell, R. C. Elliot, and M. H. Chaudhry, "Experimental results of two-dimensional dam-break flows," Journal of Hydraulic Research, vol. 30, no. 2, pp. 225-252, 1992.

[8] D. L. Fread, A breach erosion model for earthen dams. National Weather Service (NWS) Report, NOAA, Silver Spring, Mass, USA, 1984.

[9] D. L. Fread, DAMBRK: The NWS Dam Break Flood Forecasting Model. National Weather Service (NWS) Report, NOAA, SilverSpring, Mass, USA, 1984.

[10] C. Dang, P. Cui, and Z. L. Cheng, "The formation and failure of debris flow-dams, background, key factors and model tests: case studies from China," Environmental Geology, vol. 57, no. 8, pp. 1901-1910, 2009.

[11] M. Foster, R. Fell, and M. Spannagle, "The statistics of embankment dam failures and accidents," Canadian Geotechnical Journal, vol. 37, no. 5, pp. 1000-1024, 2000.

[12] G. W. Harris and D. A. Wagner, Outflow from breached earth dams, Department of Civil Engineering, University of Utah, Salt Lake City, Utah, USA, 1967.

[13] V. D. Q. Nogueira, A Mathematical Model of Progressive Earth Dam Failure, Colorado State University, Fort Collins, Colo, USA, 1984.

[14] R. Z. 1. Xie, Dam hydralics, Shangdong Science and Technology Press, Jinan, China, 1989.

[15] P. Cui, Y. Y. Zhu, Y. S. Han, X. Q. Chen, and J. Q. Zhuang, "The 12 May Wenchuan earthquake-induced landslide lakes: Distribution and preliminary risk evaluation," Landslides, vol. 6, no. 3, pp. 209-223, 2009.

[16] N. Liu, Danger relief and hazard mitigation of Dammed lakes formed by large-scale landslides, Technology and Disaster Relief Forum, plenary report, Chengdu, China, 2008. 


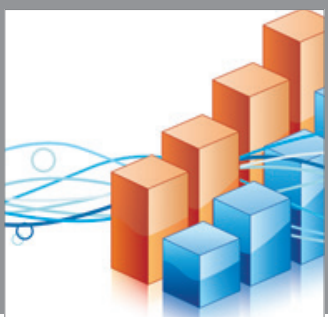

Advances in

Operations Research

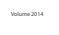

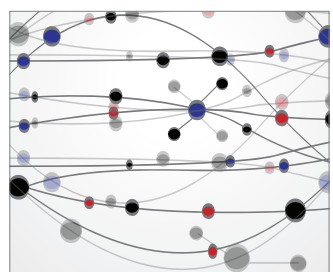

\section{The Scientific} World Journal
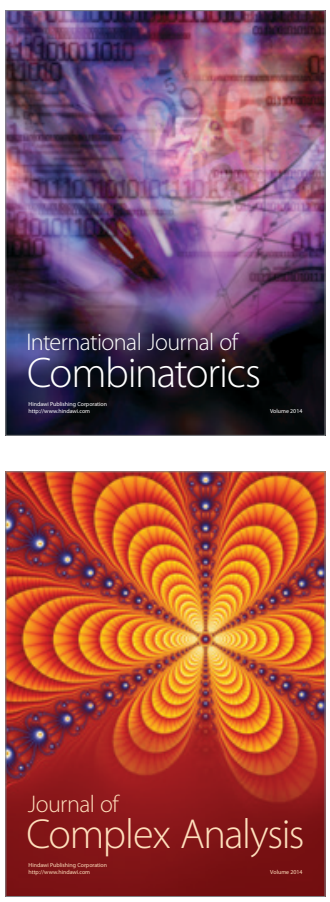

International Journal of

Mathematics and

Mathematical

Sciences
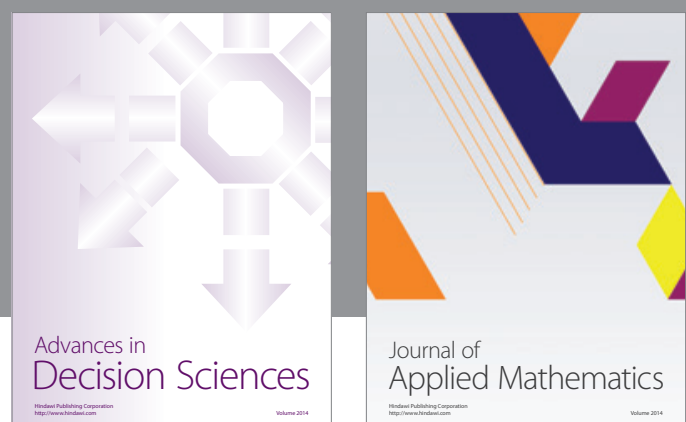

Journal of

Applied Mathematics
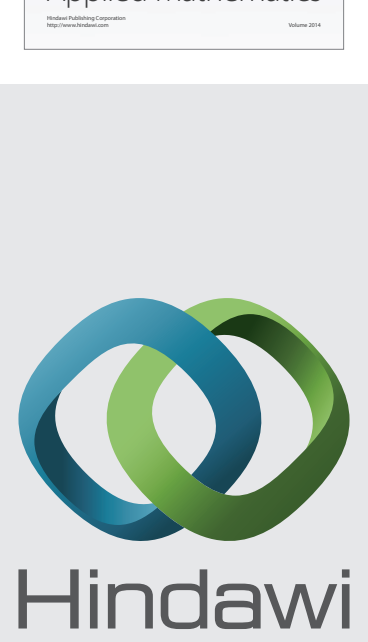

Submit your manuscripts at http://www.hindawi.com
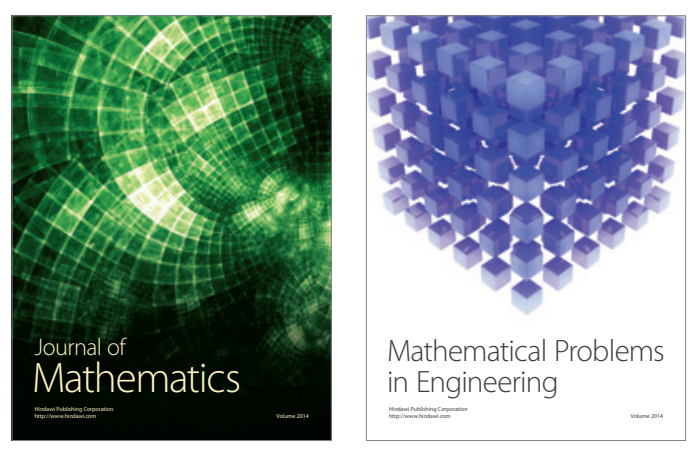

Mathematical Problems in Engineering
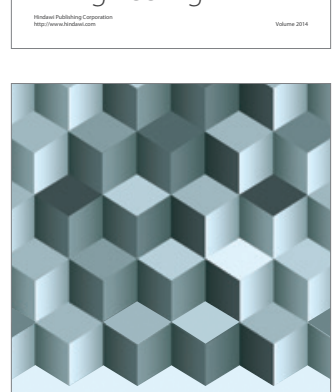

Journal of

Function Spaces
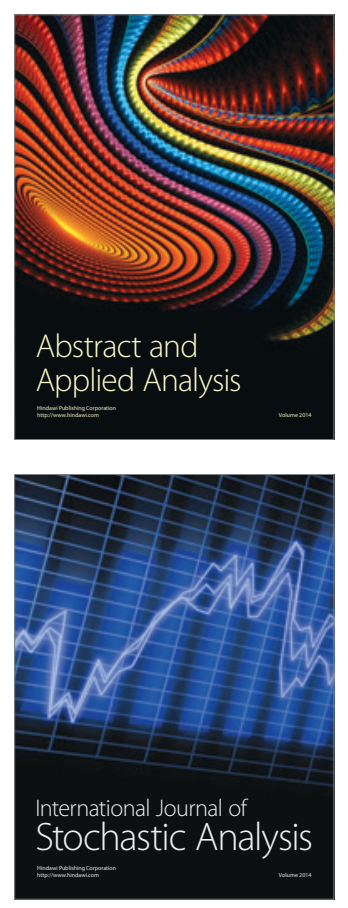

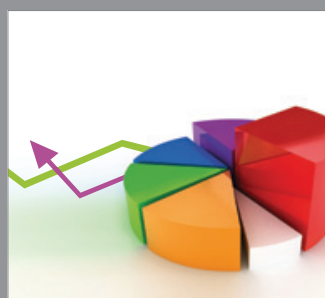

ournal of

Probability and Statistics

Promensencen
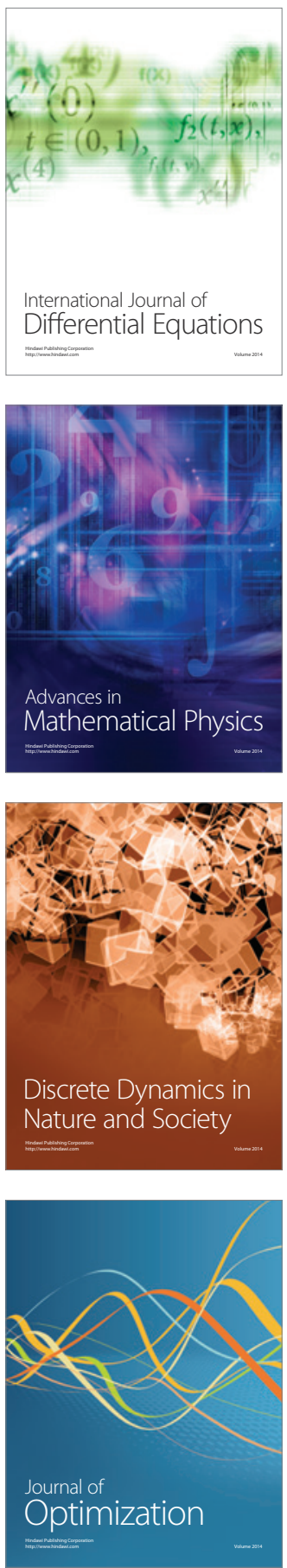